\title{
KONTRIBUSI PERILAKU KEPEMIMPINAN KEPALA SEKOLAH TERHADAP SEMANGAT MENGAJAR GURU
}

\author{
Noor Fazariah Handayani
}

FKIP Universitas Achmad Yani Banjarmasin

noorfazariah@uay.ac.id

\section{INFO ARTIKEL}

Riwayat Artikel:

Diterima: 27-Maret-2021

Disetujui: 31-Maret-2021

\section{Kata Kunci:}

Kontribusi Perilaku

Kepemimpinan Semangat

Mengajar
ABSTRAK

\begin{abstract}
Abstrak: Penelitian ini dilatarbelakangi oleh lambannya peningkatan mutu pendidikan di Indonesia, khususnya sebagian Wilayah Kecamatan Alalak Kabupaten Barito Kuala. Menurunnya nilai kelulusan terjadi karena beberapa penyebab, di antaranya semangat mengajar guru. Penelitian ini diadakan dengan tujuan untuk mengetahui seberapa besar kontribusi perilaku kepemimpinan kepala sekolah terhadap semangat mengajar guru SDN se-Kecamatan Alalak Kabupaten Barito Kuala. Dari populasi 294 orang didapatkan sampel sebanyak 169 orang dengan menggunakan teknik proportional random sampling yang tersebar di 30 sekolah. Data dikumpulkan melalui angket. Instrumen pada angket dilakukan Uji Validitas dan Reliabilitas. Selanjutnya data dilakukan Uji Normalitas, Uji Homogenitas, dan Uji Linieritas, kemudian data dianalisis dengan regresi dengan taraf signifikansi 0,05 dan besar kontribusi dari $R$ Square. Hasil analisis regresi diketahui: Terdapat kontribusi yang signifikan dari perilaku kepemimpinan kepala sekolah terhadap Semangat Mengajar guru SDN se-Kecamatan Alalak Kabupaten Barito Kuala, dengan besar koefisien determinasi $R^{2}(R$ square $)$ sebesar $0,031(3,1 \%)$ termasuk dalam kategori sedang.
\end{abstract}

Abstract: This research is motivated by the slow improvement in the quality of education in Indonesia, especially in parts of Alalak District, Barito Kuala Regency. The decline in passing scores occurred due to several reasons, including the teacher's enthusiasm for teaching. This study was conducted with the aim of knowing how much the contribution of the principal's leadership behavior towards the teaching spirit of elementary school teachers in Alalak District, Barito Kuala Regency. From a population of 294 people, a sample of 169 people was obtained using a proportional random sampling technique spread across 30 schools. Data were collected through a questionnaire. The instrument in the questionnaire was tested for validity and reliability. Furthermore, the data was carried out by the Normality Test, Homogeneity Test, and Linearity Test, then the data were analyzed by regression with a significance level of 0.05 and the size of the contribution from $R$ Square. The results of the regression analysis show: There is a significant contribution of the principal's leadership behavior to the Teaching Spirit of elementary school teachers in Alalak District, Barito Kuala Regency, with the coefficient of determination R2 (R square) of 0.031 (3.1\%) which is included in the moderate category.

This is an open access article under the $\mathbf{B Y}-\mathrm{NC}-\mathrm{ND}$ license

\section{A. LATAR BELAKANG}

Terwujudnya Sumber Daya Manusia (SDM) yang bermutu, pemerataan peluang pembelajaran, tingkatkan kualitas serta kesejahteraan tenaga kependidikan, dan memberdayakan lembaga pembelajaran/sekolah selaku pusat pembudayaan nilai, perilaku, serta pembangunan kepribadian bangsa, merupakan komitmen Dinas Pendidikan Kabupaten Barito Kuala. Serta mewujudkan tujuan tersebut yang wajib ditunjang oleh kepemimpinan kepala sekolah dan tenaga kependidikan yang handal dan bermutu.

Rivai (2011) mengemukakan profesionalisme pelayanan dalam pembelajaran merupakan kata kunci yang wajib dikedepankan dalam rangka desentralisasi pembelajaran. Terwujudnya profesionalisme pelayanan pendidikan tidak terlepas dari mutu sumber energi manusia. Bersumberpada hal tersebut menampilkan betapa besar kedudukan kepemimpinan dalam suatu organisasi, sehingga seseorang pemimpin diharapkan memiliki keahlian memimpin, mempengaruhi dalam memastikan tujuan organisasi, mempengaruhi untuk perbaikan kelompok dan budayanya, memotivasi, memusatkan, menggerakkan, pengorganisasian dan aktivitas yang mencapai target, memelihara dan menjalankan kerjasama dan berbicara dengan bawahannya untuk 
memaksimalkan kemampuan dan potensi yang dimiliki bawahannya agar tujuan organisasi dapat tercapai (Rivai \& Mulyadi, 2011).

Menurut Wahjosumidjo (2008) salah satu aspek menentukan keberhasilan dan keberlangsungan sesuatu organisasi yaitu pemimpin. Dalam konteks persekolahan, pemimpin diartikan kepala sekolah dengan tugas selaku pemimpin dan pengelola. Sebagai orang yang memimpin, seorang kepala sekolah dituntut untuk melasanakan kegiatan kepemimpinan. Kepemimpinan kepala sekolah dimaksud yaitu usaha kepala sekolah dalam mempengaruhi, mendorong, membimbing, dan menggerakkan guru, staf, siswa, orang tua siswa dan pihak lain yang terkait untuk bekerja/berperanserta agara mencapai tujuan yang sudah ditetapkan. Sebaiknya sebagai orang yang mengelola sekolah, seorang kepala sekolah dituntut sanggup mengatur segala kemampuan sekolah berperan maksimal.

Di samping peran selaku pemimpin, kepala sekolah sekaligus berperan sebagai supervisor. Keahlian supervisi kepala sekolah sangat mempengaruhi dalam menciptakan pelayanan pendidikan dan pembelajaran pendidik dan tenaga kependidikan yang bermutu. Pelaksanaan supervisi oleh kepala sekolah diharapkan mampu mempengaruhi kinerja guru dan sanggup mengembangkan potensi yang ada pada guru dalam melaksanakan tugasnya sebagai pendidik profesional secara efektif, sebagaimana diamanatkan oleh Undang-Undang Nomor 14 tahun 2005 Pasal 1 ayat (1) bahwa: Guru merupakan pendidik profesional dengan tugas utama mendidik, mengajar, membimbing, mengarahkan, melatih, menilai, dan mengevaluasi peserta didik pada pendidikan anak usia dini jalur pendidikan formal, pendidikan dasar, dan pendidikan menengah. Dan sudah sewajarnya jika para guru mengharapkan saran dan bimbingan dari kepala sekolah mereka. Oleh karena itu, mutu kepemimpinan kepala sekolah dan kemampuan supervisi kepala sekolahmerupakan kunci keberhasilan sekolah.

Pemicu rendahnya mutu pembelajaran, salah satunya disebabkan oleh semangat mengajar guru yang dalam hal ini masih rendah. Aswandi (2010) menyatakan bahwa semangat mengajar guru dipengaruhi oleh beberapa faktor, antara lain alasan menjadi guru, identitas dan integritas guru, perilaku kepemimpinan kepala sekolah, orientasi supervisi pembelajaran, keterlibatan guru dalam pengambilan keputusan, dan iklim atau atmosfir organisasi sekolah, serta tingakat kepuasan guru dalam bekerja.

Penelitian Salingkat tentang Kontribusi Perilaku Kepemimpinan Kepala Sekolah dan Motivasi Kerja Guru Terhadap Kinerja Mengajar Guru SMAN Se-Kota Palangka Raya menyatakan terdapat kontribusi yang signifikan dari perilaku kepemimpinan kepala sekolah terhadap kinerja mengajar guru SMAN Se-Kota Palangka Raya, dengan besar pengaruhnya sebanyak 6,6\% termasuk dalam kategori tinggi, dan Terdapat kontribusi yang signifikan secara bersama-sama antara perilaku kepemimpinan kepala sekolah dan motivasi kerja guru terhadap kinerja mengajar guru SMAN Se-Kota Palangka Raya besar pengaruhnya sebanyak 10,1\% termasuk dalam kategori tinggi (Salingkat, 2013).

Sulthon (2009) menyatakan bahwa semangat mengajar guru memiliki hubungan yang sangat signifikan dengan prestasi belajar siswa, dengan kontribusi 57,53\%. Penelitian oleh Masyhud pada tahun 2000 (Sulthon, 2009) menunjukkan semangat mengajar guru memiliki hubungan yang signifikan dengan semangat belajar siswa dengan kontribusi 49,34\%. Adanya hubungan antara semangat mengajar guru dengan prestasi belajar dan semangat belajar siswa menyimpulkan betapa pentingnya nilai semangat mengajar guru terhadap peningkatan kualitas proses dan hasil pembelajaran di sekolah.

Bersumber pada penjelasan dan hasil-hasil riset tentang semangat mengajar guru tersebut menunjukkan betapa berartinya perilaku kepemimpinan kepala sekolah terhadap kenaikan mutu pembelajaran di sekolah. Tetapi kenyataan di lapangan menunjukkan banyak ditemukan kepala sekolah khususnya Kepala Sekolah Dasar Negeri di Wilayah UPTD Kecamatan Alalak yang kurang memberikan teladan berupa perilaku kepemimpinan yang baik, sehingga guru-guru kurang bersemangat dalam menjalankan tugas-tugas sekolah dan merasa tidak perlu ikut bertanggung jawab atas kegagalan ataupun keberhasilan, yang berakibat pada kepuasan kerja serta semangat mengajar guru. Oleh sebab itu hal-hal yang berkaitan dengan besar rendahnya semangat mengajar guru perlu dikaji lebih lanjut, supaya membagikan masukan untuk pembinaan terhadap semangat mengajar guru, terutama guru Sekolah Dasar Negeri yang ada di Kecamatan Alalak, Kabupaten Barito Kuala.

Rumusan Masalah penelitian ini adalah Seberapa besar kontribusi perilaku kepemimpinan kepala sekolah terhadap semangat mengajar guru. Tujuan Penelitian yaitu untuk Mengetahui seberapa besar kontribusi perilaku kepemimpinan kepala sekolah terhadap semangat mengajar guru SDN Se-Kecamatan Alalak Kabupaten Barito Kuala.

\section{B. METODE PENELITIAN}

Metode riset ini merupakan metode deskriptif kuantitatif, ialah sesuatu cerminan secara sistematis, faktual dan akurat mengenai kenyataan serta sifat-sifat dan ikatan antara peristiwa yang diselidiki. Penelitian ini bertujuan untuk mengetahui kontribusi variabel bebas terhadap variabel terikat memakai teknik analisis regresi sederhana. Data penelitian dikelompokkan dalam dua variabel, yaitu satu variabel bebas dan satu variabel terikat. 
Variabel bebas adalah perilaku kepemimpinan kepala sekolah (X) dan variabel terikat adalah semangat mengajar guru (Y) dalam bentuk angket atau kuesioner.

Perilaku kepemimpinan kepala sekolah dan semangat mengajar guru adalah objek penelitian ini, dengan Subjek guru SDN yang berstatus PNS di wilayah Kecamatan Alalak Kabupaten Barito Kuala. Populasi penelitian adalah 294 guru PNS yang tersebar di 30 SDN wilayah UPTD Dinas Pendidikan Kecamatan Alalak. Sampel penelitian berjumlah 169 orang dengan responden uji coba sebanyak 30 orang. Penarikan sampel dengan teknik Proportional Random Sampling yaitu pengambilan sampel dari anggota populasi secara acak dan proporsional (Arikunto, 2014) menggunakan ukuran sampel oleh Slovin dengan resiko salah 5 persen.

Perilaku Kepemimpinan Kepala Sekolah meliputi sub variabel keterbukaan, perhatian terhadap bawahan, interaksi, dan pengambilan kebijakan keputusan (Wahjosumidjo, 2008). Semangat Mengajar Guru meliputi sub variabel kesemangat kerjaan dalam melaksanakan tugas, bertanggung jawab penyelesaian tugas, kesungguhan dalam memecahkan masalah yang dihadapi, meningkatkan usaha dalam melaksanakan KBM, mengembangkan alat pelajaran, adanya inovasi dan kreativitas, melakukan penilaian hasil belajar, dan melakukan pengajaran remedial dan pengayaan (Gibson, 2000).

Data yang didapat kemudian ditabulasikan dan dihitung berdasatkan jumlah item kuesioner dari seluruh jawaban responden, kemudian dilaksanakan uji data persyaratan analisis yaitu normalitas, homogenitas, dan linearitas. Dilanjutkan dengan analisa regresi linier sederhana untuk mengetahui besaran kontribusi perilaku kepemimpinan kepala sekolah.

Adapun rumusan hipotesis yang diajukan untuk menggambarkan kontribusi tersebut adalah sebagai berikut.

Ho : Tidak terdapat kontribusi perilaku kepemimpinan kepala sekolah terhadap Semangat Mengajar guru

SDN Se-Kecamatan Alalak Kabupaten Barito Kuala.

$\mathrm{Ha}$ : Terdapat kontribusi perilaku kepemimpinan kepala sekolah terhadap Semangat Mengajar SDN Se-

Kecamatan Alalak Kabupaten Barito Kuala.

Kriteria: Tolak Ho apabila $F_{\text {hitung }}>F_{\text {tabel }}$ atau (SIG) F $<0,05$ (taraf signifikansi).

\section{HASIL DAN PEMBAHASAN}

Analisis hasil angket sebagai alat penggali data utama untuk menggali data tentang perilaku kepemimpinan kepala sekolah dan semangat mengajar guru. Kedua variabel tersebut dideskripsikan berupa skala Likert dalam bentuk skor dengan nilai tertinggi 5 (lima) dan terendah 1 (satu). Perhitungan uji angket menampilkan bahwa nilai skor Cronbach's Alpha lebih besar dari $r_{\text {tabel }}=0,344$ yang berarti reliabel.

Tabel 1. Tingkat Skor Perilaku Kepemimpinan

\begin{tabular}{clccc}
\hline No & \multicolumn{1}{c}{ Skor } & F & Persentase & Klasifikasi \\
\hline 1 & Skor $\geq 124,67$ & 70 & $41,42 \%$ & Tinggi \\
2 & $79,33<$ Skor $<124,67$ & 99 & $58,58 \%$ & Sedang \\
3 & Skor $\leq 79,33$ & 0 & $0 \%$ & Rendah \\
\hline & Jumlah & 169 & & \\
\hline
\end{tabular}

Tabel 2. Tingkat Skor Semangat Mengajar Guru

\begin{tabular}{ccccc}
\hline No & Interval & F & Persentase & Klasifikasi \\
\hline 1. & Skor $\geq 110$ & 23 & $13,61 \%$ & Tinggi \\
2. & $70<$ Skor $<110$ & 146 & $86,39 \%$ & Sedang \\
3. & Skor $\leq 70$ & 0 & $0,00 \%$ & Rendah \\
\hline & Jumlah & $\mathbf{1 6 9}$ & $\mathbf{1 0 0 \%}$ & \\
\hline
\end{tabular}

Data penelitian pada Tabel 1 dan 2 memperlihatkan bahwa sebagian besar perilaku kepemimpinan kepala sekolah SDN se-Kecamatan Alalak Kabupaten Barito Kuala berada pada pada klasifikasi tinggi dengan persentase sebesar $41,42 \%$, dan pada klasifikasi sedang dengan persentase sebesar $58,58 \%$. Sedangkan klasifikasi rendah dengan persentase sebesar 0,00\%, sebagian besar tingkat Semangat Mengajar guru SDN seKecamatan Alalak Kabupaten Barito Kuala berada klasifikasi sedang dengan persentase sebesar 86,39\%, dan sisanya sebagian kecil berada pada klasifikasi tinggi dengan persentase sebesar 13,61\% dan klasifikasi rendah dengan persentase sebesar $0,00 \%$.

Tabel 3. Uji Normalitas Data Penelitian

\begin{tabular}{rrr}
\hline \multicolumn{3}{c}{ One-Sample Kolmogorov-Smirnov Test } \\
\hline $\mathrm{N}$ & KEPEMIMPINAN & \multicolumn{1}{c}{ SEMANGAT } \\
\hline & 169 & 169
\end{tabular}




\begin{tabular}{llrr} 
Normal Parameters & Mean & 121.5089 & 103.6272 \\
& Std. Deviation & 17.05946 & 5.70793 \\
Most Extreme Differences & Absolute & .250 & .091 \\
& Positive & .250 & .091 \\
& Negative & -.224 & -.051 \\
Kolmogorov-Smirnov Z & & 3.248 & 1.189 \\
Asymp. Sig. (2-tailed) & .000 & .118 \\
\hline a. Test distribution is Normal. & & \\
b. Calculated from data. & &
\end{tabular}

Berdsarkan Tabel 3 diperoleh besar koefisien Kolmogorov-Smirnov Z untuk variabel perilaku kepemimpinan kepala sekolah sebesar 2,259 dan Semangat Mengajar Guru sebesar 1,729. Karena nilai diperoleh tersebut lebih besar dari 0,05 maka dapat dikatakan bahwa kedua variabel tersebut terdistribusi normal. Demikian halnya jika dilihat dari nilai signifikansi dimana kedua variabel tersebut memperoleh masingmasing 0,000 dan 0,01 yang lebih kecil dari 0,05 sehingga dapat dikatakan bahwa kedua variabel tersebut terdistribusi normal.

Tabel 4. Uji Homogenitas

\begin{tabular}{|c|c|}
\hline \multicolumn{2}{|c|}{ Test of Homogeneity of Variances } \\
\hline & Levene Statistic df1 df2 Sig. \\
\hline KEPEMIMPINAN & $2.319 \quad 21 \quad 142.002$ \\
\hline
\end{tabular}

Pada tabel di atas terlihat nilai Levene Statistic hasil pengujian homogenitas data penelitian adalah 2,319 yang lebih besar dari 0,05 , maka semua varians populasi data adalah homogen.

Tabel 5. Uji Linearitas Data Penelitian

\begin{tabular}{|c|c|c|c|c|c|c|}
\hline \multicolumn{7}{|c|}{ ANOVA Table } \\
\hline & & Sum of Squares & $\mathrm{Df}$ & Mean Square & $F$ & Sig. \\
\hline \multirow{5}{*}{$\begin{array}{l}\text { SEMANGAT * Between } \\
\text { KEPEMIMPINAN Groups }\end{array}$} & (Combined) & 994.522 & 29 & 34.294 & 1.064 & .390 \\
\hline & Linearity & 170.716 & 1 & 170.716 & 5.298 & .023 \\
\hline & Deviation from Linearity & 823.807 & 28 & 29.422 & .913 & .595 \\
\hline & Within Groups & 4478.992 & 139 & 32.223 & & \\
\hline & Total & 5473.515 & 168 & & & \\
\hline
\end{tabular}

Interprestasinya adalah: lihat kolom Sig. pada baris Linearity di Table Anova sebesar 0,023 dan 0,034, karena nilainya $<0,05$ maka bersifat linear sehingga dapat disimpulkan memenuhi syarat linearitas.

Tabel 6. Analisa Regresi Linier Sederhana

\begin{tabular}{llccccc}
\hline \multicolumn{7}{c}{ ANOVA $^{\mathbf{b}}$} \\
\hline Model & & Sum of Squares & df & Mean Square & F & Sig. \\
\hline 1 & Regression & 170.716 & 1 & 170.716 & 5.376 & $.022^{\mathbf{a}}$ \\
& Residual & 5302.799 & 167 & 31.753 & & \\
& Total & 5473.515 & 168 & & & \\
\hline
\end{tabular}

a. Predictors: (Constant), KEPEMIMPINAN

b. Dependent Variable: SEMANGAT

Berdasarkan hasil analisis secara regresi linear sederhana pada Tabel 6, terlihat bahwa nilai SIG dari kontribusi perilaku kepemimpinan kepala sekolah terhadap Semangat Mengajar guru adalah sebesar 0,022 dan signifikansinya adalah 0,05. karena nilai dari $S I G=0,022<0,05$, maka $H a$ diterima. Dengan ini diperoleh kesimpulan bahwa "terdapat kontribusi Perilaku Kepemimpinan Kepala Sekolah terhadap Semangat Mengajar guru SDN Se-Kecamatan Alalak Kabupaten Barito Kuala". 
Tabel 7. Besar Kontribusi Perilaku Kepemimpinan Kepala Kepemimpinan Kepala Sekolah Terhadap Semangat Mengajar Guru

Model Summary ${ }^{\mathrm{b}}$

Model R R Square Adjusted R Square Std. Error of the Estimate

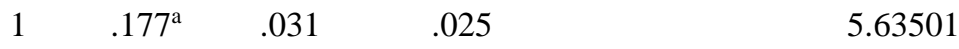

a. Predictors: (Constant), KEPEMIMPINAN

b. Dependent Variable: SEMANGAT

Tabel 7 memperlihatkan besar koefisien determinasi $R^{2}(R$ Square) adalah sebesar 0,031 (3,1\%). Hal ini memperlihatkan bahwa besar kontribusi perilaku kepemimpinan kepala sekolah terhadap Semangat Mengajar guru SDN Se-Kecamatan Alalak Kabupaten Barito Kuala adalah sebesar 3,1\%.

Tabel 8. Tabel Persamaan Regresi Perilaku Kepemimpinan Kepala Sekolah Terhadap Semangat Mengajar Guru Coefficients $^{\mathrm{a}}$

\begin{tabular}{|c|c|c|c|c|c|c|}
\hline & \multirow[b]{2}{*}{ Model } & \multicolumn{3}{|c|}{ Unstandardized Coefficients Standardized Coefficients } & \multirow[b]{2}{*}{$\mathrm{t}$} & \multirow[b]{2}{*}{ Sig. } \\
\hline & & $\mathrm{B}$ & Std. Error & Beta & & \\
\hline 1 & (Constant) & 96.447 & 3.127 & & 30.846 & .000 \\
\hline & PEMIMPINAN & .059 & .025 & .177 & 2.319 & .022 \\
\hline
\end{tabular}

a. Dependent Variable: SEMANGAT

Analisis data pada Tabel 8 terlihat besar koefisien dari variabel kepemimpinan kepala sekolah adalah 0,059 dan konstantanya adalah sebesar 96,447. sehingga persamaan regresi dari kepemimpinan kepala sekolah terhadap Semangat Mengajar guru SDN Se-Kecamatan Alalak Kabupaten Barito Kuala adalah $\mathrm{Y}=96,447+0,059 \mathrm{X} 1$. Berdasarkan persamaan tersebut, diketahui bahwa setiap kenaikan satu skor perilaku kepemimpinan kepala sekolah akan meningkatkan Semangat Mengajar guru sebesar 0,059 dan sebaliknya apabila terjadi penurunan satu skor kepemimpinan kepala sekolah maka akan menurunkan Semangat Mengajar guru sebesar 0,059 .

Hal ini sesuai dengan pendapat pendapat Tannembaum, Weshler \& Massarik, (1961) tentang definisi kepemimpinan sebagai berikut: "Leadership is interpersonal influence exercised in a situation, and directed through the communication process, toward the attainment of a specified goal or goals" (Wahjosumidjo, 2008). Perihal ini sejalan dengan pendapat Majid (2005) yang menerangkan bahwasanya guru, murid, serta bahan ajar ialah aspek yang dominan dalam proses pembelajaran di kelas. Ketiga aspek ini saling berhubungan, saling memberi pengaruh, serta saling menunjang antara satu dengan yang lain. Apabila salah satu aspek tidak terdapat, maka kedua aspek lain tidak dapat berhubungan secara wajar dan proses pembelajaran tidak bisa berlangsung secara baik. Menurutnya dalam konteks ini guru berfungsi sebagai pembuat keputusan yang berhubungan dengan perencanaan, implementasi, dan evaluasi (Majid, 2005).

Semangat mengajar guru menurut Davis (Wibowo, 2016) adalah seperangkat perasaan pegawai tentang mengasyikkan atau tidaknya pekerjaan mereka. Kemudian Robin (Chanata, 2010) memberitahukan semangat mengajar guru terpaut erat dengan sikap pekerja yaitu guru yang memperhitungkan perbandingan antara jumlah imbalan yang sepatutnya dengan kenyataan yang diterimanya.

Semangat mengajar guru sebagai pendidik diperlukan untuk tingkatkan kualitas pembelajaran, perihal ini disebabkan semangat mengajar guru akan berakibat pada prestasi kerja dan kualitas kerjanya serta yang akhirnya memberi dampak positif pada prestasi belajar siswa. Guru yang mempunyai semangat mengajar besar akan menyukai pekerjaannya yang kemungkinan akan memberi dampak yang positif pada peningkatan kualitas pembelajaran dan mutunya pendidikan. Demikian juga sebaliknya, guru yang mempunyai semangat mengajar rendah akan memberi dampak terhadap perkembangan kualitas pendidikan yang tercermin pada perilakunya yang kerap membolos, mengajar tanpa perencanaan, sering mengeluh, dan sebagainya.

Dengan demikian, dalam meningkatkan semangat mengajar guru, maka kepala sekolah sebaiknya juga terus meningkatkan mutu sikap perilaku kepemimpinannya, seperti dinyatakan oleh Wahjosumidjo (2008) yang meliputi: (a) Keterbukaan kepala sekolah dalam gaya kepemimpinan dilihat dari merumuskan kebijakan dengan bermusyawarah, mendelegasikan tugas dengan jelas dan penerapan tata tertib organisasi; (b) Atensi terhadap bawahan, diindikasikan dari membentuk pekerjaan supaya bias dilaksanakan, tingkatkan moral dan semangat staf, membagikan ganjaran atas usaha perorangan, membagikan dorongan dan penghargaan, membantu staf mengatasi masalahnya dan keramahan dalam melakukan pendekatan; (c) Interaksi terefleksi ditafsirkan selaku perilaku kepemimpinan sebagai usaha membina ikatan hubungan harmonis; dan (d) Pengambil keputusan, 
dimana kepala sekolah mengembangkan tingkatan nilai-nilai kehidupan sekolah yang demokratis serta perduli terhadap lingkungan sekolah.

Disamping itu kepala sekolah sebaiknya mensosialisasikan program kerja sekolah beserta standar minimum keberhasilan yang diharapkan seluruh warga sekolah, terutama guru. Tidak hanya itu, kepala sekolah wajib terus berupaya tingkatkan kepekaan terhadap perubahan yang terjadi sehingga mampu menjadi pionir dan motivator untuk guru juga karyawan agar terus melaksanakan perubahan kearah yang lebih baik.

Guru dituntut untuk terus mempertahankan dan lebih meningkatkan semangat mengajarnya dengan menggunakan manfaat dari sikap perilaku kepemimpinan kepala sekolah. Melalui perilaku kepemimpinan kepala sekolah yang berorientasi tugas, akan menghasilkan ikatan hubungan harmonis antara kepala sekolah dengan guru sehingga dapat mengembangkan tingkatan semangat mengajarnya, dan mempermudah guru dalam menlaksanakan tugas-tugasnya lebih optimal dan maksimal karena mereka mengetahui lebih jelas dan tepat akan tugas-tugasnya, program sekolah, maupun standar pencapaian hasil yang diharapkan sekolah. Guru disini berperan sebagai fasilitator dan mediator yang memungkinkan terciptanya keadaan kondusif dalam belajar dan bertanggung jawab atas terpenuhinya hasil pembelajaran peserta didik. Kerena itu, untuk menciptakan kualitas pendidikan bermutu tercermin dengan dihasilkannya peserta didik berprestasi maksimal, diperlukan guru yang mempunyai semangat mengajar yang baik atau guru yang berkualitas dan bermutu baik.

\section{SIMPULAN DAN SARAN}

Kesimpulan yang didapat dari penelitian ini bahwa Terdapat kontribusi yang signifikan dari perilaku kepemimpinan kepala sekolah terhadap Semangat Mengajar guru SDN se-Kecamatan Alalak Kabupaten Barito Kuala, dengan besar koefisien determinasi $R^{2}(R$ square) adalah sebesar $0,031(3,1 \%)$ dan termasuk dalam kategori sedang.

Kepemimpinan kepala sekolah merupakan proses mempersatukan pikiran, ide, serta pendapat dalam mewujudkan kesatuan gerak yang terencana dan terarah pada pencapaian tujuan lingkungan. Personel sekolah, yang didalamnya memiliki makna menggerakkan, memotivasi orang lain maupun kelompok supaya bersedia melaksanakan tugas-tugas selaku rekan kerja di sekolah. Dengan penafsiran tersebut, maka perilaku kepemimpinan kepala sekolah SDN se-Kecamatan Alalak Kabupaten Barito Kuala memiliki peran penting terhadap Semangat Mengajar guru.

Adapun saran yang perlu disampaikan kepada pihak terkait, antara lain: Kepala sekolah sebaiknya meningkatkan kemampuannya dalam memimpin sebuah sekolah, salah satu caranya adalah dengan memperbaiki perilaku kepemimpinannya dalam hal keterbukaan dan perhatian terhadap bawahan, interaksi, karena faktor-faktor tersebut memiliki kontribusi yang baik dalam meningkatkan Semangat Mengajar guru; Guru harus berperan lebih akif dalam progam sekolah, dengan memberikan berbagai pendapat dan kritik membangun dalam kepemimpinan juga dalam keterlibatan dalam berbagai kegiatan di sekolah; Dinas pendidikan Kecamatan Alalak perlu mempertimbangkan seleksi rekrutmen calon kepala sekolah dengan aspek yang sudah terstandarisasi sesuai peraturan yang berlaku; dan bagi penelitian selanjutnya, disarankan untuk meneliti lebih jauh mengenai faktor-faktor yang dapat mempengaruhi Semangat Mengajar guru selain perilaku kepemimpinan kepala sekolah.

\section{DAFTAR RUJUKAN}

[1] Arikunto, Suharsimi. 2014. Prosedur Penelitian Suatu Pendekatan Praktik (Edisi Revisi V). Jakarta: Rineka Cipta.

[2] Cherington, David J. 1995. Organizational Behavior: The Management Of Individual and Organizational Performance. Advision of Simon of Schilter Inc.

[3] Depdiknas. 2013. Undang-Undang Nomor 20 Tahun 2013 Tentang Sistem pendidikan Nasional. Jakarta: Depdiknas.

[4] Gibson, James L, et.all,. 2000. Organisasi Perilaku, Struktur, Proses, Alih bahasa Djarkasih. Jakarta: Erlangga.

[5] Majid, Nurcholis. 2005. Membudayakan Etos Kerja. Jakarta: Rineka Cipta.

[6] Rivai, Veithzal dan Deddy Mulyadi. 2011. Kepemimpinan dan Perilaku Organisasi, Edisi Ketiga. Jakarta: Raja Grafindo Persada.

[7] Salingkat. 2013. Kontribusi Perilaku Kepemimpinan Kepala Sekolah Dan Motivasi Kerja Guru Terhadap Kinerja Mengajar Guru Sman Se-Kota Palangka Raya. Banjarmasin: Jurnal Penelitian Universitas Lambung Mangkurat. Tidak diterbitkan.

[8] Sulthon. 2009. Membangun Semangat Kerja Guru. Yogyakarta: Leks Bang Presindo.

[9] Peraturan Pemerintah Republik Indonesia Nomor 74 Tahun 2008. Tentang Guru. Jakarta. Depdiknas. 
[10] Undang-Undang RI Nomor 14 tahun 2005 tentang Guru dan Dosen

[11] Wahjosumidjo. 2007. Kepemimpinan dan Motivasi. Jakarta: Ghalia Indonesia.

[12] Wahjosumidjo. 2008. Kepemimpinan Kepala Sekolah, Tinjauan Teoritik dan Permasalahannya. Jakarta: Raja Grafindo Persada.

[13] Wibowo. 2016. Manajemen Kinerja Edisi Kelima. Jakarta: Rajawali Pers. 